\title{
Nutritional value, total dry matter losses, effluent production and pollutant potential in Brachiaria brizantha cv. Paiaguás grass
}

[Valor nutricional, perdas totais de matéria seca, produção e potencial poluidor de efluentes em silagem de Brachiaria brizantha cv. Paiaguás]

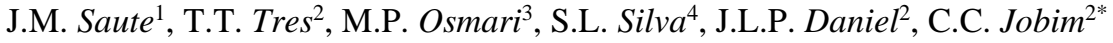 \\ ${ }^{1}$ Aluno de pós graduação - Universidade Estadual de Maringá - Maringá, PR \\ ${ }^{2}$ Universidade Estadual de Maringá - Maringá, PR \\ ${ }^{3}$ Universidade Federal de Santa Catarina - Florianópolis, SC \\ ${ }^{4}$ Universidade do Estado de Mato Grosso - Cáceres MT
}

\begin{abstract}
The objective of the present study was to evaluate losses, production and polluting potential of the effluent, nutritional value and aerobic stability of silages of Brachiaria brizantha cv. Paiaguás grass, in different particle sizes and compaction density in silage. Three theoretical particle sizes (TTP 5;8 and 12mm) and three compaction densities (DC 550; 600 and $650 \mathrm{~kg} / \mathrm{m}^{3}$ ) were evaluated, distributed in a factorial design (3 $\mathrm{x} 3$ ), with four repetitions. The highest volume of effluent was found in silages with higher compaction densities $\left(600\right.$ and $\left.650 \mathrm{~kg} / \mathrm{m}^{3}\right)$ and lower TTP $(5$ and $8 \mathrm{~mm})$. The highest chemical oxygen demand and biochemical oxygen demand were registered in the treatment with TTP of $5 \mathrm{~mm}$ and higher DC (600 and $\left.650 \mathrm{~kg} / \mathrm{m}^{3}\right)$. Greater in vitro digestibility of DM was verified in the silage chopped at 5 and $8 \mathrm{~mm}$. There was no break in aerobic stability for 216 hours. Silage with a low compaction density $550 \mathrm{~kg} / \mathrm{m}^{3}$ and processing with a theoretical particle size of $12 \mathrm{~mm}$ reduces effluent losses. In general, the nutritional value of Paiaguás grass was not influenced by the treatments. Different particle sizes and compaction density did not change the aerobic stability of silages.
\end{abstract}

Keywords: compaction, oxygen demand, in vitro digestibility, conserved forage, particle size

\section{RESUMO}

Objetivou-se avaliar perdas, produção e potencial poluidor do efluente, valor nutricional e estabilidade aeróbia de silagens do capim Brachiaria brizantha cv. Paiaguás, em diferentes tamanhos de partícula e densidade de compactação na ensilagem. Foram avaliados três tamanhos teóricos de partícula (TTP 5; 8 e $12 \mathrm{~mm}$ ) e três densidades de compactação (DC 550; 600 e $\left.650 \mathrm{~kg} / \mathrm{m}^{3}\right)$, distribuídos em arranjo fatorial ( 3 x 3), com quatro repetições. O maior volume de efluente foi verificado nas silagens com maiores densidades de compactação $\left(600\right.$ e $\left.650 \mathrm{~kg} / \mathrm{m}^{3}\right)$ e menores TTP $(5$ e $8 \mathrm{~mm})$. As maiores demanda química de oxigênio e demanda bioquímica de oxigênio foram registradas no tratamento com TTP de $5 \mathrm{~mm}$ e nas maiores DC $\left(600\right.$ e $650 \mathrm{~kg} / \mathrm{m}^{3}$ ). Maior digestibilidade in vitro da MS (média de 57,2\%) foi verificada na silagem picada a 5 e $8 \mathrm{~mm}$. Não houve quebra da estabilidade aeróbia durante 216 horas. A ensilagem com baixa densidade de compactação $\left(550 \mathrm{~kg} / \mathrm{m}^{3}\right)$ e o processamento com tamanho teórico de partículas $12 \mathrm{~mm}$ reduzem as perdas por efluente. $O$ valor nutricional da silagem de capim-paiaguás, em geral, não foi influenciado pelos tratamentos. Diferentes tamanhos de partícula e densidade de compactação não alteraram a estabilidade aeróbia das silagens.

Palavras-chave: compactação, demanda de oxigênio, digestibilidade in vitro, forragem conservada, tamanho de partícula

Recebido em 2 de outubro de 2020

Aceito em 9 de fevereiro de 2021

*Autor para correspondência (corresponding author)

E-mail: ccjobim@uem.br 


\section{INTRODUCTION}

The Brachiaria genus corresponds to forages of African origin, widespread in the Brazilian territory, mainly due to its characteristic high yield of dry matter (DM), easy establishment, resistance to illness and good vegetative growth throughout the year (Silva et al., 2016). Besides this, in proper management situations, they present good nutritional composition (Cruvinel et al., 2017). This context implies the need to develop technologies and good practices for production and conservation with smaller loss of dry matter. Silage is a technology that can be used successfully in the conservation of grass, with the aim to preserve the nutritional value of the forage. However, care must be taken with the silage of forage with DM below $21 \%$, soluble carbohydrates below $2.2 \%$ and low relation between carbohydrates and sealing, for they present greater risk for the occurrence of secondary fermentation (McDonald et al., 1991).

Inadequate fermentation results in loss of nutrients, elevated concentration of butyric acid, ammonia, amines and acetic acid, which reduce the consumption of silage with consequent fall in animal performance (Jobim and Nussio, 2013). Furthermore, silages with high humidity present significant production and release of effluents to the environment, contributing with pollution, especially when reaching the water courses, where macrobiotic flora demands high quantities of oxygen during metabolism (Loures et al., 2003). This situation renders the environment anaerobic, risking the life of other aquatic organisms (Schmidt et al., 2011), and this is the main environmental concern regarding the release of silage effluents (Savoie and Jofriet, 2003; Borreani et al., 2017).

In general, it is observed that the density of compaction in silage, the size of the particle and production of effluents are related (Loures et al., 2003, 2005), however, work that uses Brachiaria brizantha grass for silage are scarce in literature. Due to this, the objective of this research was to evaluate total loss of dry matter, production and potential pollution of effluent, nutritional value and aerobic stability of silage in Brachiaria brizantha $\mathrm{cv}$. Paiaguás grass, in different particle sizes and compaction density in the silage.

\section{MATERIAL AND METHODS}

The experiment was conducted at the Fazenda Experimental de Iguatemi (FEI), which belongs to the State University of Maringá, located in the district of Iguatemi $\left(23^{\circ} 25^{\prime} 38^{\prime \prime} \mathrm{S}\right.$ and $\left.51^{\circ} 56^{\prime} 15^{\prime \prime} \mathrm{O}\right)$ in the state of Paraná, Brazil. The climate in the region is type $\mathrm{Cfa}$, meaning humid mesothermic subtropical, according to the Köppen classification (Produção..., 1994), with average temperature and precipitation of $22{ }^{\circ} \mathrm{C}$ and $1,200 \mathrm{~mm}$, respectively. Rain has a seasonal distribution with well-defined dry and rainy seasons and the soil is classified as Red Dystrophic Latosolo (Sistema..., 2018; Manual..., 2007). The experimental period ranged from December 13, 2016 to May 17, 2017, and the climatic data was collected from the FEI Meteorological Station (Figure 1). Paiaguás grass (Brachiaria brizantha cv. Paiaguás) was established in a 1ha area in a corrected and fertilized soil, according to the results of soil analysis (Table 1).

The soil preparation was conventional (disc plough and levelling grid). The sowing of Paiaguás grass was done by throwing, on December 13,2016 , with a sowing rate of $15 \mathrm{~kg}$ $\mathrm{ha}^{-1}$, using a fertilizer and seed distributor of the Vicon ${ }^{\circledR}$ brand. After the establishment of the grass, urea based nitrogenated fertilization was done $\left(60 \mathrm{~kg} \mathrm{ha}^{-1} \mathrm{~N}\right)$. After 30 days of establishment, the height of the grass was monitored weekly, through measuring 30 random points, using a $100 \mathrm{~cm}$ ruler to follow the growth of the grass and determine the ideal height for cut and silage.

The cut of Brachiaria brizantha cv. Paiaguás was done in a development stage that contemplated the balance of the quality and quantity of the forage mass available (beginning of flowering) at a height of $10 \mathrm{~cm}$ from soil level (Cândido et al., 2008). This moment occurred when the pasture presented, on average, $49.8 \mathrm{~cm}$ height, meaning 63 days after emergence. The cut was done with a harvester model JF92Z10 ${ }^{\circledR}$, regulated for the predefined heights as treatments. The evaluated treatments had three theoretical particle sizes $(5$; 8 and $12 \mathrm{~mm}$ ) and three silage compacting densities $\left(550 \mathrm{~kg} / \mathrm{m}^{3} ; 600 \mathrm{~kg} / \mathrm{m}^{3}\right.$ and $\left.650 \mathrm{~kg} / \mathrm{m}^{3}\right)$, distributed in a factorial arrangement $(3 \times 3)$ with four repetitions (silos) each. 


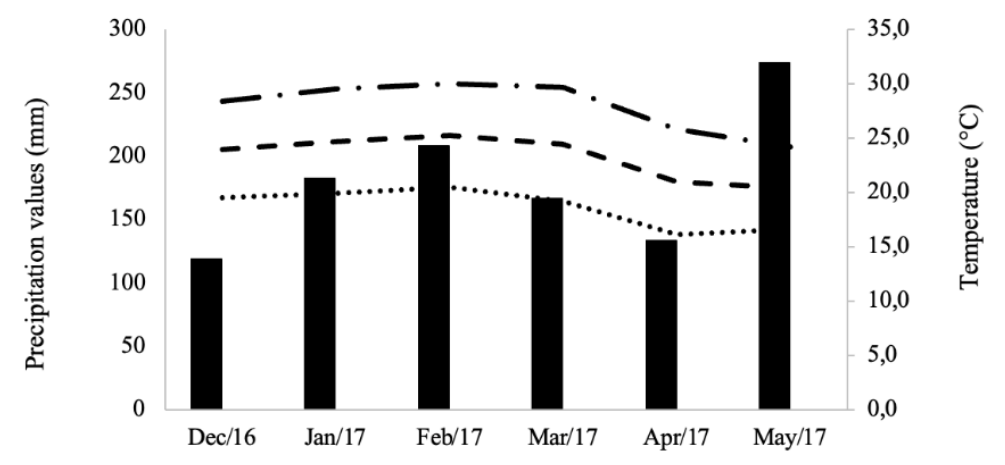

Experimental Period

Precipitation

$\mathrm{T}^{\circ} \mathrm{C}$ Minimum

- $-\mathrm{T}^{\circ} \mathrm{C}$ Average

Figure 1. Average precipitation $(\mathrm{mm})$ and ambient temperature (maximum, minimum and average) $\left({ }^{\circ} \mathrm{C}\right.$ ) during the experimental period of Brachiaria brizantha cv. Paiaguás grass, silage. Source: Meteorological Station at Fazenda Experimental de Iguatemi, Iguatemi, PR.

Table 1. Chemical composition of the soil (0-20 cm deep) in the experimental area of Brachiaria brizantha cv. Paiaguás grass, in the beginning of the evaluation period

\begin{tabular}{|c|c|c|c|c|c|c|c|c|c|c|c|c|}
\hline $\mathrm{pH}$ & $\mathrm{H}^{+}$ & $\mathrm{Al}^{3+}$ & $\mathrm{H}^{+}+\mathrm{Al}^{3+}$ & $\mathrm{Ca}^{2+}$ & $\mathrm{Mg}^{2+}$ & $\mathrm{K}^{+}$ & $\mathrm{Ca}^{+}+\mathrm{Mg}+$ & SB & CTC & V & P & OM \\
\hline $\begin{array}{ll}\mathrm{CaCl} & \mathrm{H} 2 \mathrm{O} \\
\end{array}$ & \multicolumn{9}{|c|}{$\mathrm{Cmol}_{\mathrm{c}} \cdot \mathrm{dm}^{-3}$} & $\%$ & mg.dm ${ }^{-3}$ & g. $\mathrm{dm}^{-3}$ \\
\hline 6.30 & 3.30 & 0.0 & 3.30 & 4.41 & 2.00 & 0.25 & 6.41 & 6.60 & 9.96 & 66.9 & 7.29 & $8.82 \quad 15.2$ \\
\hline
\end{tabular}

Source: Sociedade Rural de Maringá Laboratory.

The silage was done in experimental PVC silos, with a volume of $0.013 \mathrm{~m}^{3}$ which allowed the silage of up to $8.45 \mathrm{~kg}$ of grass, obeying the densities defined as treatments. After filling, the silos were sealed with a black canvas and a heavy transparent adhesive tape. At the base of the silos a plastic bag was places to collect effluents, being sealed with adhesive tape to not allow the loss of produced liquid and the entrance of oxygen. The silos were stored in a covered area for 90 days, a period where there was the collection of effluent in order to determine the volume produced and evaluate its polluting potential. As it was produced, the effluent was removed from the collector bag, measured in a graduated beaker, and transferred to an opaque plastic container with a $200 \mathrm{~mL}$ capacity, duly identified and stored at $20^{\circ} \mathrm{C}$ for posterior laboratory analysis. At the moment of collection, the $\mathrm{pH}$ of effluents was measured with the use of a digital measuring device by TECNAL, model Tec-3MP.

At the end of 90 days of storage, the total volume of effluents produced was determined. Of these, effluent samples were collected from approximately $30 \mathrm{~mL}$ per repetition in each treatment and sent to the Laboratório de
Qualidade de Água e Controle de Poluição (Environmental Sanitation), belonging to the Universidade Estadual de Maringá, for the following analysis: Chemical Oxygen Demand (QOD) and Biochemical Oxygen Demand (BOD), according to APHA protocol (Standart..., 1995). The variables $\mathrm{pH}$ and loss of $\mathrm{DM}$ were analyzed through effluent according to methodology proposed by Schmidt (2007).

After 90 days of storage the silos were weighed to determine total loss of DM, and open to remove samples (approximately $500 \mathrm{~g} / \mathrm{silo}$ ) for chemical bromatological analysis, electrical conductivity (EC) according to Kraus et al. (1997) and to determine $\mathrm{pH}$ in the silage according to Cherney and Cherney (2003). After the collection of samples, the silos were decompressed to simulate the discharge conditions (Kung Jr., 2000). The material was later placed back into the silos, and during the next ten days, in two periods (10am and $2 \mathrm{pm}$ ) the environment and silage (in the silos) temperatures were recorded through a digital thermometer, model Gulterm 1001, to evaluate the aerobic stability.

The DM losses (DML) of the silage were estimated, according to the equation: DML = 
$[(D M i-D M f) / D M i] x 100$. Where DMi $=$ initial dry matter and DMf = final dry matter (silo weight), according to the equation proposed by Jobim et al. (2007). The samples collected at the moment of silage, as well as those collected after opening the silos (approximately 500g) were dried in a forced air ventilation chamber at $55^{\circ} \mathrm{C}$, ground in a cutting mill with a $1 \mathrm{~mm}$ mesh sieve and sent to the Laboratório de Nutrição e Alimentação Animal - LANA (belonging to the Universidade Estadual de Maringá) for the following determinations: dry matter (DM, method 967.03), crude protein (CP, method 990.03), mineral matter (MM, method 942.05) and ether extract (EE, method 920.39) done according to AOAC (Official..., 1990).

In a sequential manner the levels of NDF were determined according to Mertens (2002), and ADF according to Van Soest (1973) and lignin (Van Soest et al., 1991). Cellulose (CEL) and hemicellulose (HEM) were determined from the difference between NDF - lignin and NDF $\mathrm{ADF}$, respectively $(\mathrm{CEL}=\mathrm{ADF}-\mathrm{LIG}$ and HEM $=\mathrm{NDF}-\mathrm{ADF})$. The total carbohydrates $(\mathrm{CT})$ were obtained by the sequence proposed by Sniffen et al., (1992): CT = MO - (EE + PB). The chemical composition of Brachiaria brizantha cv. Paiaguás grass at the moment of cut was DM content 20.7\%; CP content $10.2 \%$; NDF content $65.8 \%$; EE content $1.6 \%$ and TC of $79.8 \%$.

The in vitro digestibility of dry matter (IVDDM) was determined using the Daisy Incubator Ankom ${ }^{\circledR}$ equipment, according to Holden (1999). The variable data obtained from silages were analyzed for each particle size, compaction density and interaction between both effects. The data obtained were submitted to variance analysis according to statistical analysis SAS (Property..., 1999), using the GLM procedure, where the averages were compared with the aid of the Tukey Test at $5 \%$ probability and the mathematical model used was:

$$
\mathrm{Y}_{\mathrm{ij}}=\mu+\mathrm{D}_{\mathrm{i}}+\varepsilon_{\mathrm{i}}+\mathrm{P}_{\mathrm{j}}+(\mathrm{DP})_{\mathrm{ij}}+\varepsilon_{\mathrm{ij}} \text {, where: }
$$

$Y_{\mathrm{ij}}=$ value observed for the variable response to the effect of density $i$ and the size of particle $\mathrm{j} ; \mu$ $=$ average of treatments; $\mathrm{D}_{\mathrm{i}}=$ effect of density $i, \mathrm{i}$ $=550 \mathrm{~kg} / \mathrm{m}^{3} ; 600 \mathrm{~kg} / \mathrm{m}^{3}$ and $650 \mathrm{~kg} / \mathrm{m}^{3} ; \varepsilon_{\mathrm{i}}=$ random error associated to parcel $i ; \mathrm{P}_{\mathrm{j}}=$ effect of the average size of the particle $j, \mathrm{j}=5 \mathrm{~mm} ; 8 \mathrm{~mm}$ and
$12 \mathrm{~mm} ;(\mathrm{DP})_{\mathrm{ij}}=$ interaction between treatments $i^{*} j$; $\varepsilon_{\mathrm{ij}}=$ random error associated to sub parcel $i j$.

\section{RESULTS AND DISCUSSION}

The greatest losses in dry matter in the silos (Table 2) were verified in the treatments with greater compacting densities $\left(600\right.$ and $\left.650 \mathrm{~kg} / \mathrm{m}^{3}\right)$, which may be attributed to the pressure applied to the mass, which associated with the low DM content in the culture at the time of silage $(20.7 \%)$, favors the leakage of cellular content (Jobim and Nussio, 2013; Borreani et al., 2017), as verified in this work, with greater effluent volume produced in these treatments (Table 3).

The size of the particle didn't influence the electrical conductivity (EC) of the ensiled mass, which was only influenced by the density of compacting at the moment of silage $(\mathrm{P}<0.05$; Table 2). The greatest EC value was registered when using the $600 \mathrm{~kg} / \mathrm{m}^{3}(1533.9 \mu / \mathrm{cm})$ density, being similar to the lowest compacting density of $550 \mathrm{~kg} / \mathrm{m}^{3}(1437.7 \mu / \mathrm{cm})$. The measurement of the electrical conductivity of the material in analysis evaluates the intensity of the cellular rupture of the forage submitted to cut and consequent leaching of ions for the solution. Therefore, the greatest concentration of free ions with the rupture of the cellular wall occurs due to the process of fermentation or mechanical effect in the act of ensiling the culture (Bumbieris Junior et al., 2010).

The $\mathrm{pH}$ of the silage was influenced by the theoretical size of the particle and by the density of compaction in the silage $(\mathrm{P}<0.05$; Table 2$)$. The greatest value for $\mathrm{pH}(5.07)$ was registered in the silage with greatest theoretical particle size $(12 \mathrm{~mm})$ and in the compacting density of $600 \mathrm{~kg} / \mathrm{m}^{3}$. The lactic acid is the main product of fermentation responsible for the reduction in $\mathrm{pH}$, however, its combination with the other fermentation products is what determines the final $\mathrm{pH}$ of the ensiled material (Pahlow et al., 2003). Grass silages naturally present greater $\mathrm{pH}$ than the observed in whole plant corn silages, for example, this is due to the low concentration of DM in these cultures, average concentration of soluble carbohydrates and high buffer capacity, which limits the capacity for fermentation (Jobim and Nussio, 2013). Elevated $\mathrm{pH}$ values, in a grass silage with greater particle size was also verified in the work by Loures et al. (2005). The lowest 
verified $\mathrm{pH}$ in the silages with smaller particle size ( 5 and $8 \mathrm{~mm}$ ) is due to the fact that the smaller particles compact better and release greater amount of soluble carbohydrates for fermentation (Holmes, 2009).

Table 2. Dry matter losses (DML), electrical conductivity (EC) and pH of silages of Brachiaria brizantha cv. Paiaguás grass processed in different sizes of particles and different densities of compaction in the opening of silos

\begin{tabular}{|c|c|c|c|c|c|c|c|c|c|c|}
\hline \multirow{2}{*}{ Variable } & \multicolumn{3}{|c|}{ Particle size (mm) } & \multicolumn{3}{|c|}{$\begin{array}{c}\text { Compaction density } \\
\left(\mathrm{kg} / \mathrm{m}^{3}\right)\end{array}$} & \multirow[t]{2}{*}{ SEM } & \multicolumn{3}{|c|}{ P - Valor } \\
\hline & 5 & 8 & 12 & 550 & 600 & 650 & & $\mathrm{P}$ & D & $\mathrm{P} \times \mathrm{D}$ \\
\hline $\begin{array}{l}\text { DML }(\%) \\
\text { through silage }\end{array}$ & 10,66 & 12.36 & 9.56 & $3.76^{\mathrm{b}}$ & $13.55^{\mathrm{a}}$ & $15.54^{\mathrm{a}}$ & 1.167 & 0.3006 & $<0.0001$ & 0.2077 \\
\hline $\mathrm{EC}(\mu / \mathrm{cm})$ & 1418.34 & 1505.20 & 1376.68 & $1437.7^{\mathrm{ab}}$ & $1533.9^{\mathrm{a}}$ & $1324.3^{\mathrm{b}}$ & 35.49 & 0.228 & 0.0428 & 0.6734 \\
\hline Silage $\mathrm{pH}$ & $4.39^{\mathrm{b}}$ & $4.49^{\mathrm{b}}$ & $5.07^{\mathrm{a}}$ & $4.5^{\mathrm{b}}$ & $4.8^{\mathrm{a}}$ & $4.6^{\mathrm{b}}$ & 0.07 & $<0.0001$ & 0.01 & 0.59 \\
\hline
\end{tabular}

Different lowercase letters in the same line differ through the Tukey test $(\mathrm{P}<0.05)$. SEM $=$ standard error from the mean, $\mathrm{P}=$ effect of particle size, $\mathrm{D}=$ effect of density, $\mathrm{P} \times \mathrm{D}=$ interaction between the average particle size of the forage and density, $\mathrm{EC}=$ electrical conductivity.

There was an effect of the theoretical particle size and compaction density (Table 3), with greater loss of DM through effluent verified in the theoretical particle size $8 \mathrm{~mm}$ and in the greater compacting densities $\left(600\right.$ and $\left.650 \mathrm{~kg} / \mathrm{m}^{3}\right)$. The dry matter content in the plant below $25 \%$ favors the effluent losses (Jobim and Nussio, 2013). Associated to this is the greater processing of the plant in the reduction of particle size and greater pressure applied to the mass due to compacting is what justifies the greater amount of DM loss though effluent in the treatments mentioned (Jobim et al., 2007; Holmes, 2009). Just as greater DM loss through effluent, the greater volume of effluent was verified in the treatments with densities of 600 and $650 \mathrm{~kg} / \mathrm{m}^{3}$. Regarding the theoretical particle size, the greater effluent volume was verified in treatments with 5 and $8 \mathrm{~mm}$. There was significant interaction $(\mathrm{P}<0.05)$ between the average size of the particle and the compaction density in the production of effluent.

The production of effluent was considerable, on average $14.7 \mathrm{~L} / \mathrm{t}$ of ensiled material. This may be attributed to the low content of DM in the silages, which was an average of $20.7 \%$ at the moment of cutting, associated with a greater reduction of the particle size and pressure applied to the mass, which favors leaching of liquids from the cells. This liquid is composed mainly of water, but also carries soluble substances, nutrients which constitute loss of dry matter (Savoie and Jofriet, 2003; Jobim and Nussio, 2013). It is in this sense that the production of effluents deserves attention due to the nature of leached products and the reduction of silage quality. Soluble composts such as: sugars, nitrogen, organic acids, vitamins and minerals may also be present in the effluent produced in the silages. It is also highly relevant to consider the possible environmental impacts that occur due to these effluents (McDonald et al., 1991).

In the characterization of produced effluents, a significative interaction $(\mathrm{P}<0.05)$ was present between particle size and compaction density. The greatest values of COD and BPD were registered in the effluent of the silage with smallest theoretical particle size of $5 \mathrm{~mm}$, followed by the treatment with particle size of $8 \mathrm{~mm}$, the greatest values of COD and BOD were also verified in the treatments with greatest compaction density $\left(600 \mathrm{~kg} / \mathrm{m}^{3}\right.$ and $\left.650 \mathrm{~kg} / \mathrm{m}^{3}\right)$. These were also the treatments where the silages presented greatest effluent production, thus, greater nutrient loss. The COD is the amount of oxygen $(\mathrm{mg} / \mathrm{L})$ necessary to stabilize the organic matter through the application of a strong oxidative (potassium dichromate), and BOD is the amount of oxygen $(\mathrm{mg} / \mathrm{L})$ necessary for the aerobic microorganisms to stabilize the organic matter (constituted basically of sugars, proteins, fats, minerals, and other) present in the effluent (Valente et al., 1997).

The leached from the silos sent to the environment is a factor of great importance related to the silage of grass with high humidity. Since the effluent has a great biochemical demand of $\mathrm{O}_{2}$ it can quickly deplete the $\mathrm{O}_{2}$ in the water, and consequently kill the aquatic life. In sandy and permeable soil, the effluent of the silage may also contaminate 
subterraneous water. (Savoie and Jofriet, 2003). The ratio COD/BOD related to the particle sizes $5 ; 8$ and $12 \mathrm{~mm}$ was 3,$18 ; 2.74$ and 4.66 respectively, and for evaluated densities 550; 600 and $650 \mathrm{~kg} / \mathrm{m}^{3}$ it was $4.00 ; 2.9$ and 3.28 . The average COD/BOD ratio was 3,5 units. The easily biodegradable residue was considered as that with a COD/BOD ratio below 2, recommending the conventional biological treatment. However, the COD/BOD above 2 indicates the existence of non-biodegradable dry matter, needing, therefore, a physical-chemical treatment (Braile and Cavalcanti, 1993). Consequently, the effluent must be treated, and for this the initial step is its capture in a reservoir (Savoie and Jofriet, 2003).

Table 3. Dry matter losses (DML), production and characterization of effluent deriving from silages of Brachiaria brizantha cv. Paiaguás grass ensiled in different particle sizes and compaction densities

\begin{tabular}{|c|c|c|c|c|c|c|c|c|c|c|}
\hline \multirow[t]{2}{*}{ Variable } & \multicolumn{3}{|c|}{ Particle size (mm) } & \multicolumn{3}{|c|}{$\begin{array}{c}\text { Compaction Density } \\
\left(\mathrm{kg} / \mathrm{m}^{3}\right)\end{array}$} & \multirow[t]{2}{*}{ SEM } & \multicolumn{3}{|c|}{ P - Valor } \\
\hline & 5 & 8 & 12 & 550 & 600 & 650 & & $\mathrm{P}$ & D & $\mathrm{P} \times \mathrm{D}$ \\
\hline $\begin{array}{l}\text { DML }(\%) \\
\text { through effluent }\end{array}$ & $8.10^{\mathrm{b}}$ & $11.16^{\mathrm{a}}$ & $6,86^{\mathrm{b}}$ & $2.9^{\mathrm{b}}$ & $12.1^{\mathrm{a}}$ & $11.9^{\mathrm{a}}$ & 0.92 & 0.003 & $<.0001$ & 0.03 \\
\hline $\begin{array}{l}\text { Production of } \\
\text { effluent }(\mathrm{L} / \mathrm{t})\end{array}$ & $14.39^{\mathrm{a}}$ & $15.02^{\mathrm{a}}$ & $5.60^{\mathrm{b}}$ & $6.50^{\mathrm{b}}$ & $14.8^{\mathrm{a}}$ & $14.4^{\mathrm{a}}$ & 1.30 & $<.0001$ & $<.0001$ & $<.0001$ \\
\hline COD (mg/L) & $18.97^{\mathrm{a}}$ & $12.09^{\mathrm{b}}$ & $9.70^{c}$ & $10.8^{b}$ & $14.8^{\mathrm{a}}$ & $15.1^{\mathrm{a}}$ & 1.10 & $<.0001$ & $<.0001$ & $<.0001$ \\
\hline BOD (mg/L) & $5.96^{\mathrm{a}}$ & $4.41^{\mathrm{b}}$ & $2.08^{c}$ & $2.7^{\mathrm{b}}$ & $5.1^{\mathrm{a}}$ & $4.6^{\mathrm{a}}$ & 0.50 & $<.0001$ & $<.0001$ & $<.0001$ \\
\hline $\mathrm{pH}$ of effluent & 8.04 & 8.46 & 7.93 & 7.8 & 8.3 & 8.3 & 0.14 & 0.2003 & 0.19 & 0.4541 \\
\hline
\end{tabular}

Different lowercase letters in the same line differ through the Tukey test $(\mathrm{P}<0.05)$. SEM $=$ standard error from the mean, $\mathrm{P}=$ effect of particle size, $\mathrm{D}=$ effect of density, $\mathrm{P} \times \mathrm{D}=$ interaction between the average particle size of the forage and density, $\mathrm{DML}=$ dry matter loss via effluent, Production $=$ production of effluent, $\mathrm{COD}=$ chemical oxygen demand, $\mathrm{BOD}=$ biochemical oxygen demand.

Table 4. Bromatological composition and in vitro digestibility of Brachiaria brizantha cv. Paiaguás grass, ensiled in different particle sizes and compacting densities

\begin{tabular}{|c|c|c|c|c|c|c|c|c|c|c|}
\hline \multirow{2}{*}{$\begin{array}{c}\text { Variables } \\
(\%)\end{array}$} & \multicolumn{3}{|c|}{ Particle size $(\mathrm{mm})$} & \multicolumn{3}{|c|}{$\begin{array}{c}\text { Compacting Density } \\
\left(\mathrm{kg} / \mathrm{m}^{3}\right)\end{array}$} & \multirow[b]{2}{*}{ EPM } & \multicolumn{3}{|c|}{ P-Valor } \\
\hline & 5 & 8 & 12 & 550 & 600 & 650 & & $\mathrm{P}$ & $\mathrm{D}$ & $\mathrm{P} \times \mathrm{D}$ \\
\hline $\mathrm{DM}$ & 19.8 & 19.7 & 19.6 & 19.9 & 19.4 & 19.8 & 0.223 & 0.92 & 0.59 & 0.84 \\
\hline $\mathrm{OM}$ & 90.7 & 90.7 & 91.2 & 91.2 & 90.3 & 91.1 & 0.182 & 0.52 & 0.13 & 0.96 \\
\hline $\mathrm{CP}$ & 9.54 & 10.0 & 9.72 & 9.55 & 9.93 & 9.79 & 0.140 & 0.43 & 0.56 & 0.63 \\
\hline NDF & 64.6 & 64.1 & 65.8 & 64.5 & 64.9 & 65.0 & 0.362 & 0.15 & 0.84 & 0.43 \\
\hline $\mathrm{ADF}$ & 47.3 & 46.1 & 48.2 & 47.1 & 46.5 & 48.0 & 0.409 & 0.08 & 0.27 & 0.19 \\
\hline HEM & 17.3 & 18.0 & 17.6 & 17.4 & 18.5 & 17.0 & 0.355 & 0.67 & 0.20 & 0.12 \\
\hline CEL & 45.4 & 44.5 & 46.7 & 45.0 & 44.9 & 46.5 & 0.401 & 0.09 & 0.19 & 0.40 \\
\hline LIG & $1.98^{\mathrm{a}}$ & $1.52^{\mathrm{b}}$ & $1.54^{\mathrm{b}}$ & $2.07^{\mathrm{a}}$ & $1.49^{\mathrm{b}}$ & $1.48^{\mathrm{b}}$ & 0.083 & $<0.01$ & $<0.01$ & $<0.01$ \\
\hline $\mathrm{EE}$ & $2.61^{b}$ & $2.58^{b}$ & $2.98^{\mathrm{a}}$ & 2.63 & 2.84 & 2.69 & 0.049 & $<0.01$ & 0.08 & 0.47 \\
\hline IVDDM & $57.8^{\mathrm{a}}$ & $56.6^{\mathrm{a}}$ & $53.3^{b}$ & 55.4 & 56.7 & 55.4 & 0.623 & $<0.01$ & 0.53 & 0.43 \\
\hline
\end{tabular}

Uppercase letters in the same line differ by the Tukey test $(\mathrm{P}<0.05)$. SEM $=$ standard error on the mean; $\mathrm{P}=$ effect of particle size; $\mathrm{D}=$ effect of density; $\mathrm{P} \times \mathrm{D}=$ interaction between the average particle size in the forage and density; $\mathrm{DM}$ $=$ dry matter; $\mathrm{OM}=$ organic matter; $\mathrm{CP}=$ crude protein; $\mathrm{NDF}=$ neutral detergent fiber; $\mathrm{ADF}=$ acid detergent fiber; HEM = hemicellulose; CEL = cellulose; LIG = lignin; EE = ether extract; IVDDM = "in vitro" digestibility of DM.

There was no effect of treatments on $\mathrm{pH}$ of effluent, the values were confronted with the maximum and minimum limits established by CONAMA (Brasi, 2011), with the pH range of 5 -9 as ideal for aquatic life. Regarding the bromatological composition of the silages (Table $4)$, there was a significant difference $(\mathrm{P}<0.05)$ in the content of lignin, with greater content $(1.98 \%)$ when the silage was produced with a particle size of $5 \mathrm{~mm}$. This response may influence the loss of nutrients due to the greater production of effluents verified in this silage (Table 3), which favors a greater concentration of lignin. For the $550 \mathrm{~kg} / \mathrm{m}^{3}$ compacting density the greatest concentration of lignin was verified $(\mathrm{P}<0.05)$. Lower density may have granted higher porosity of mass and consequent loss of nutrients (Holmes, 2009), 
concentrating the fractions of more difficult degradation, such as lignin.

The silage with the largest theoretical particle size $(12 \mathrm{~mm})$ presented the greatest EE content in the silage $(\mathrm{P}<0.05)$. For Loures et al. $(2003,2005)$, the smaller particle size allowed a greater compacting degree and greater expulsion of residual oxygen, while the larger particle makes compacting more difficult and favors the presence of residual oxygen, prolongs breathing promoting the consumption of sugars and concentrating EE.

Regarding IVDDM, there was an effect of the particle size $(\mathrm{P}<0.05)$, with higher concentrations of IVDDM observed when the silage process happened with Paiaguás grass cut at $5 \mathrm{~mm}$ and $8 \mathrm{~mm}$. In the present study, the theoretical increase in particle size $(12 \mathrm{~mm})$ decreased IVDDM, this treatment also presented the greatest $\mathrm{pH}$ value (5.07). The greater particle size may have triggered the presence of more residual air in the silage, prolonging the time of cellular breathing (vegetable and microbial) and favoring the secondary fermentations, creating greater consumption of soluble nutrients, which compromises the activity of lactic acid bacteria (LAB) and the quick conservation of nutrients (Borreani et al., 2017). Consequently, the impact is seen in the reduction of potentially digestible nutrients for animals. The silos with smaller particles (5 and $8 \mathrm{~mm}$ ) presented a lower $\mathrm{pH}$, which shows a better conservation of the mass, in this case a greater IVDDM was observed, but these particle sizes favor the losses due to production of effluent.

All the silages had elevated aerobiosis stability. For all the silages, in the period of 216 hours of aerobic stability, there was no elevation in mass temperature ensiled above $2^{\circ} \mathrm{C}$ in relation to ambient temperature (Figure 2). On the other hand, a temperature fall was verified in the first 72 hours, due to the low ambient temperature $\left(19^{\circ} \mathrm{C}\right)$. A temperature rise in the silage was later registered in all treatments, following the ambient temperature.

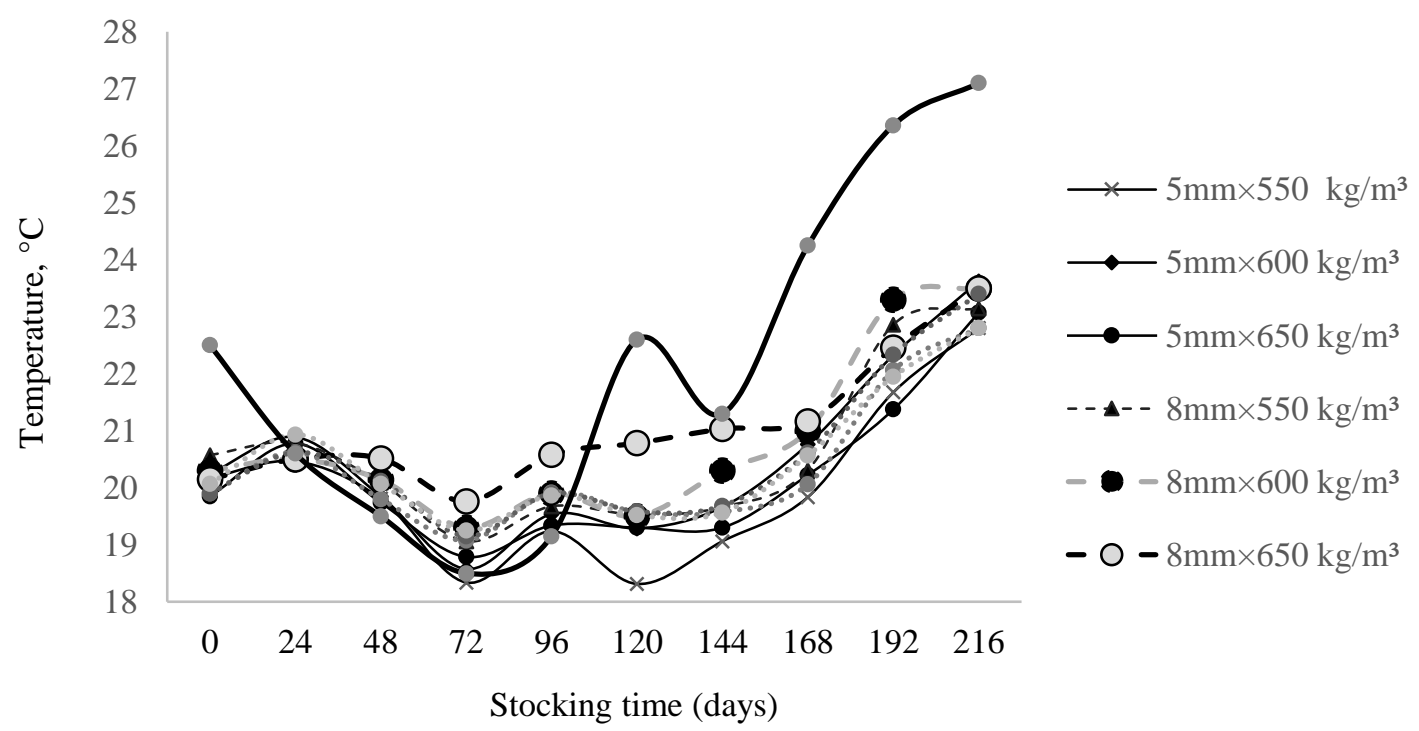

Figure 2. Temperatures of silages $\left({ }^{\circ} \mathrm{C}\right)$ during the exposure period $(\mathrm{h})$ to oxygen. $\mathrm{SEM}=0.21 ; \mathrm{P}<0.01$ for interaction between the theoretical particle size $\mathrm{x}$ density $\mathrm{x}$ time.

The fact that numerically the treatment with smaller theoretical particle size and greater compacting density $\left(5 \mathrm{~mm}\right.$ and $\left.650 \mathrm{~kg} / \mathrm{m}^{3}\right)$, in certain periods, presented higher internal temperature of the ensiled mass in relation to the others is noteworthy. This may be a result of the greater efficiency in compacting, greater expulsion of residual air, better anaerobic fermentation and greater preservation of the nutritional value of the ensiled mass, with smaller losses of soluble composts (Loures et al., 2003; Neumann et al., 2005; Amaral et al., 2007). 


\section{CONCLUSIONS}

Silage with low compacting density $\left(550 \mathrm{~kg} / \mathrm{m}^{3}\right)$ and processing with theoretical particle size of $12 \mathrm{~mm}$ reduce the effluent loss. The nutritional value of the silage of Paiaguás grass in general is not influenced by the theoretical particle size and density of silage. Different particle sizes and compacting densities do not alter the aerobic stability of the silages of Paiaguás grass.

\section{REFERENCES}

AMARAL, R.C.; BERNARDES, T.F.; SIQUEIRA, G.R.; REIS, R.A. Características fermentativas e químicas de silagens de capimmarandu produzidas com quatro pressões de compactação. Rev. Bras. Zootec., v.36, p.532-539, 2007.

BRAILE, P.M.; CAVALCANTI, J.E.W.A. Manual de tratamento de águas residuárias. São Paulo: CETESB, 1993. 764p.

BRASIL. Conselho Nacional do Meio Ambiente - CONAMA 430/2011: Condições e padrões de lançamento de efluentes complementa e altera a resolução, n.357. 2011.

BUMBIERIS JUNIOR, V.H.; JOBIM, C.C.; EMILE, J.C. et al. Aerobic stability of triticale silage in single culture or in mixtures with oat and/or legumes. R. Bras. Zootec., v.39, n.11, p.2349-2356, 2010.

BORREANI, G.; TABACCO, E.; SCHMIDT, R.J. et al. Silage review: Factors affecting dry matter and quality losses in silage. J. Dairy Sci., 101, p.3952-3979, 2017.

CÂNDIDO, M.J.D.; CUTRIN JÚNIOR, A.J.A.; SILVA, R.G.; AQUINO, R.M.S. Técnicas de fenação para a produção de leite. In: SEMINÁRIO NORDESTINO DE PECUÁRIAPEC, 2008, Fortaleza. Anais ... Fortaleza: FAEC, 2008. p.261-298.

CHERNEY, J.H.; CHERNEY, D.J.R. Assessing silage quality. In: BUXTON, D.R.; MUCK, R.E.; HARRISON, J.H. et al. (Eds.). Silage science and technology. Madison: [s.n.], 2003. p.141-198.

CRUVINEL, W.S.; COSTA, K.A.P.; TEIXEIRA, D.A.A. et al. Fermentation profile and nutritional value of sunflower silage with urochloa brizantha cultivars in the off-season. Rev. Bras. Saúde Prod. Anim., v.18, p.249-259, 2017.
HOLDEN, L.A. Comparison of methods of in vitro dry matter digestibility for feeds. J. Dairy Sci., v.82, p.1791-1794, 1999.

HOLMES, B. Software applications for sizing silos to maximize silage quality. In: INTERNATIONAL SYMPOSIUM OF FORAGE QUALITY AND CONSERVATION, 2009, Piracicaba. Proceedings... Piracicaba: FEALQ, 2009. p.189.

JOBIM, C.C.; NUSSIO, L.G. Principios basicos da fermentação na ensilagem. In: REIS, R.A.; BERNARDES, T.F.; SIQUEIRA, G.R. (Eds.) Forragicultura, ciência, tecnologia e gestão dos recursos forrageiros. Jaboticabal: Maria de Lourdes Brandel - ME, 2013. p.649-660.

JOBIM, C.C.; NUSSIO, L.G.; REIS, R.A. et al. Avanços metodológicos na avaliação da qualidade de forragem conservada. Rev. Bras. Zootec., v.36, p.101-119, 2007.

KRAUS, T.J.; KOEGER, R.G.; STRAUB, R.J. et al. Leachateconductivity as an index

for quantifyinglevelof forage conditioning. In: ASAE ANNUAL INTERNATIONALMEETING, 1997, Minneapolis. Proceedings... Minneapolis: ASAE, 1997. 12p.

KUNG JR., L.; ROSILOON, J.R.; RANJIT, K. et al. Microbial populations, fermentation andproducts, and aerobic stability of corn silage treated with ammonia or a propionic acid-based preservative. J. Dairy Sci., v.83, p.1479-1486, 2000.

LOURES, D.R.S.; GARCIA, R.; PEREIRA, et al. Características do efluente e composição químico-bromatológica da silagem de capimelefante sob diferentes níveis de compactação. Rev. Bras. Zootec., v.32, p.1851-1858, 2003.

LOURES, D.R.S.; NUSSIO, L.G.; PAZIANI, S.F. et al. Composição bromatológica e produção de efluente de silagem de capim-Tanzânia sob efeito de emurchecimento, do tamanho de partícula e do uso de aditivos biológicos. Rev. Bras. Zootec., v.34, p.726-735, 2005.

MANUAL técnico de pedologia. 2.ed. Rio de Janeiro: IBGE, 2007, p.191-195.

McDONALD, P.; HENDERSON, A.R.; HERON, S.J.E. The biochemistry of silage. 2.ed. Marlow: Chalcomb Publications, 1991. 340p. 
MERTENS, D.R. Measuring and its effectiveness in ruminants diets. In: Plains Nutrition Council Spring Conference, 2002, San Antonio. Proceedings... San Antonio, Texas: [s.n.], 2002.

NEUMANN, M.; RESTLE, J.; BRONDANI, I.L. et al. Efeito do tamanho da partícula e do tipo de silo sobre o valor nutritivo da silagem de sorgo (Sorghum bicolor, L. Moench). Rev. Bras. Milho Sorgo, v.4, p.224-242, 2005.

OFFICIAL methods of analysis. 15.ed. Washington: AOAC, 1990.

PAHLOW, G.; MUCK, R.E.; DRIEHUIS, F. et al. Microbiology of ensiling. . In: BUXTON, D.R.; MUCK, R.E.; HARRISON, J.H (Eds.). Silage science and technology. Madison, 2003. p.31-94.

PAREDES, C.; ROIG, A.; BERNAL, M.P. et al. Evolution of organic matter and nitrogen during co-composting of olive mill wastewater with solid organic wastes. Biol. Fertil. Soils, v.20, p.226236, 2000 .

PRODUÇÃO animal na agricultura familiar do Centro-sul do Paraná. Londrina: IAPAR, 1994.

PROPERTY software release. Version 8. Cary: SAS Institute, 1999. 956p.

SAVOIE, P.; JOFRIET, J.C. Silage strorage. In: BUXTOM, D.R.; MUCK R.E.; HARRISON, H.J. (Eds.). Silage science and technology. Madison: American Society of Agronomy, 2003.

SCHMIDT, P.; NOVINSKI, C.O.; JUNGES, D. Riscos ambientais oriundos de compostos orgânicos voláteis e do efluente produzido por silagens. In: SIMPÓSIO SOBRE PRODUÇÃ̃O E UTILIZAÇÃO DE FORRAGENS CONSERVADAS. 4., 2011, Maringá. Anais... Maringá: UEM, 2011. p.251270 .
SCHMIDT, P. Perdas fermentativas na ensilagem, parâmetros digestivos e desempenho de bovinos de corte alimentados com rações contendo silagens de cana-de açúcar. Rev. Bras. Zootec., v.36, n.5, 2007.

SILVA, J.L.; RIBEIRO, K.G.; HERCULANO, B.N. et al. Massa de forragem e características estruturais e bromatológicas de cultivares de Brachiaria e Panicum. Ciênc. Anim. Bras., v.17 p.342-348, 2016.

SISTEMA brasileiro de classificação de solos. 5.ed. Embrapa, 2018, p.198.

SNIFFEN, C.J.; O'CONNOR, D.J.; VAN SOEST, P.J. et al. A net carbohydrate and protein system for evaluating cattle diets: II. Carbohydrate and protein availability. J. Anim. Sci., v.70, p.3562-3577, 1992.

STANDART methods for the examination of water and wastewater.19.ed. Washington: APHA, 1995. 1268p.

VAN SOEST, P.J.; ROBERTSON, J.B.; LEWIS, B.A. Methods for dietary fiber, neutral detergent fiber, and non starch polysaccharides in relation to animal nutrition. J. Dairy Sci., v.74, p.3583-3597, 1991.

VAN SOEST, P.J. Collaborative study of acid detergente fiber and lignina. J. Assoc. Official Anal. Chem., v.56, p.781-784, 1973.

VALENTE, J.P.S.; PADILHA, P.M.; SILVA, A.M.M. Oxigênio dissolvido (OD) demanda bioquímica de oxigênio (DBO) e demanda química de oxigênio (DQO) como parâmetros de poluição no ribeirão Lavapés/Botucatu - SP. Eclética Quím., v.22, p.49-66, 1997. 